\author{
Zbigniew Zioło \\ Zakład Przedsiębiorczości i Gospodarki Przestrzennej \\ Instytut Geografii \\ Uniwersytet Pedagogiczny im. KEN w Krakowie
}

\title{
Rola przedsiębiorczości w kształtowaniu społeczeństwa informacyjnego
}

Nasilający się proces rozwoju cywilizacyjnego przejawia się w przechodzeniu od industrialnej i postindustrialnej fazy rozwoju do kształtowania się społeczeństwa informacyjnego, którego gospodarka jest oparta na wiedzy (Droga Polski..., 2005; Kukliński 2001, 2005). W tym procesie podstawową rolę odgrywają przedsiębiorcze postawy dobrze wyedukowanego społeczeństwa. Dlatego rolę przedsiębiorczości w kształtowaniu społeczeństwa informacyjnego należy uznać za bardzo ważną i analizować ją na szerszym tle ogólnej tendencji rozwoju cywilizacyjnego. Podejście to pozwoli na rozpatrywanie tej problematyki jako segmentu bardziej złożonego mechanizmu kształtującego życie społeczne, gospodarcze i kulturowe w różnych skalach przestrzennych, od układu światowego, przez układy krajowe i regionalne, do układów lokalnych. Wkraczanie w informacyjną fazę rozwoju prowadzi do zmiany bazy ekonomicznej gospodarki rozwijającej się w różnych kategorii układach przestrzennych. W tym złożonym systemie ważnym problemem wydaje się określenie miejsca przedsiębiorczości i społeczeństwa informacyjnego jako podstawowych czynników przyspieszających wkraczanie układów przestrzennych w nową fazę rozwoju cywilizacyjnego.

W poprzednich fazach rozwoju, o długotrwałym wzroście społeczno-gospodarczym i kulturowym, decydującą rolę odgrywały czynniki ilościowe, głównie ziemia, majątek trwały i zasoby siły roboczej, a także wsparty działaniami edukacyjnymi i naukowo-badawczymi rozwijający się postęp technologiczny i techniczny. W nowej fazie rozwoju, wraz ze zmieniającymi się uwarunkowaniami, coraz większą rolę będą odgrywać czynniki jakościowe: nasilający się postęp techniczny, wzrost jakości kapitału ludzkiego, kreowane instrumenty pobudzania rozwoju oraz sprawnie funkcjonujące organa instytucjonalne władzy rządowej i samorządowej. W zapewnieniu możliwie najlepszych uwarunkowań przebiegu tego procesu szczególnie znaczącą rolę będzie odgrywał kapitał ludzki. Wpływa on bowiem w decydującym stopniu na:

- generowanie postępu naukowego, technologicznego i technicznego;

- racjonalne wykorzystanie środków materialnych i kapitałowych;

- wdrażanie innowacyjnych rozwiązań w zakresie organizacji i zarządzania produkcją, usługami i obszarami rynkowymi;

- poprawne relacje firm z otoczeniem.

Sprawna koordynacja wymienionych segmentów oraz przyjęcie właściwych celów prorozwojowych prowadzi do podnoszenia konkurencyjności przedsiębiorstw, a w konsekwencji - do konkurencyjności poszczególnych sektorów i całej gospodarki, a także różnych kategorii układów przestrzennych. W świetle przedstawionych założeń będziemy zmierzać do zaprezentowania koncepcji modelu określającego miejsce przedsiębiorczości i społeczeństwa informacyjnego $\mathrm{w}$ procesie rozwoju cywilizacyjnego. 
Kapitał ludzki w ogólnym znaczeniu obejmuje wszystkie cechy psychofizyczne poszczególnych osób związane z wrodzonymi zdolnościami oraz zdobyte $\mathrm{w}$ procesie edukacyjnym zasoby wiedzy i umiejętności ich wykorzystania. Wpływają one bezpośrednio lub pośrednio na podnoszenie stopnia innowacyjności działań, które prowadzą do zwiększania wydajności pracy i podnoszenia konkurencyjności produktów; umożliwiają także utrzymywanie i pogłębianie istniejących rynków zbytu oraz opanowywanie rynków nowych. Kapitał ludzki jest nierozerwalnie związany z nośnikami nowych idei i wartości, które sprzyjają powstawaniu nowych innowacyjnych rozwiązań w zakresie tworzenia i wdrażania nowej wiedzy do produkcji, organizacji, zarządzania i administrowania. W węższym znaczeniu, przez kapitał ludzki rozumie się poziom edukacji danej osoby czy społeczeństwa mieszkającego na danym obszarze, a jego zasoby określa liczba ludności o odpowiednim poziomie wykształcenia.

Innowacyjne działania $\mathrm{w}$ gospodarce nie dokonują się samoistnie, ale w wyniku zapotrzebowania na nowe idee firm i instytucji we współdziałaniu: rządu, ludzi nauki, instytucji edukacyjnych oraz administracji samorządowej i rządowej. Bez ich współdziałania nie ma zbyt dużych szans na rozwój innowacyjnych projektów i modernizacji gospodarki, a także zmian struktur społecznych danego kraju czy określonych układów przestrzennych.

Przedsiębiorczość i społeczeństwo informacyjne nie funkcjonują w odosobnieniu, ale wykazują bardzo silne powiązania między sobą oraz z innymi elementami systemu społeczno-gospodarczego i kulturowego (ryc. 1). W zaproponowanym modelu wyróżniono zróżnicowane funkcjonalnie segmenty gospodarki, których tendencje przemian nawiązują do nasilającego się w skali światowej procesu rozwoju cywilizacji informacyjnej.

Ryc. 1. Miejsce przedsiębiorczości i społeczeństwa informacyjnego w systemie społeczno-gospodarczym

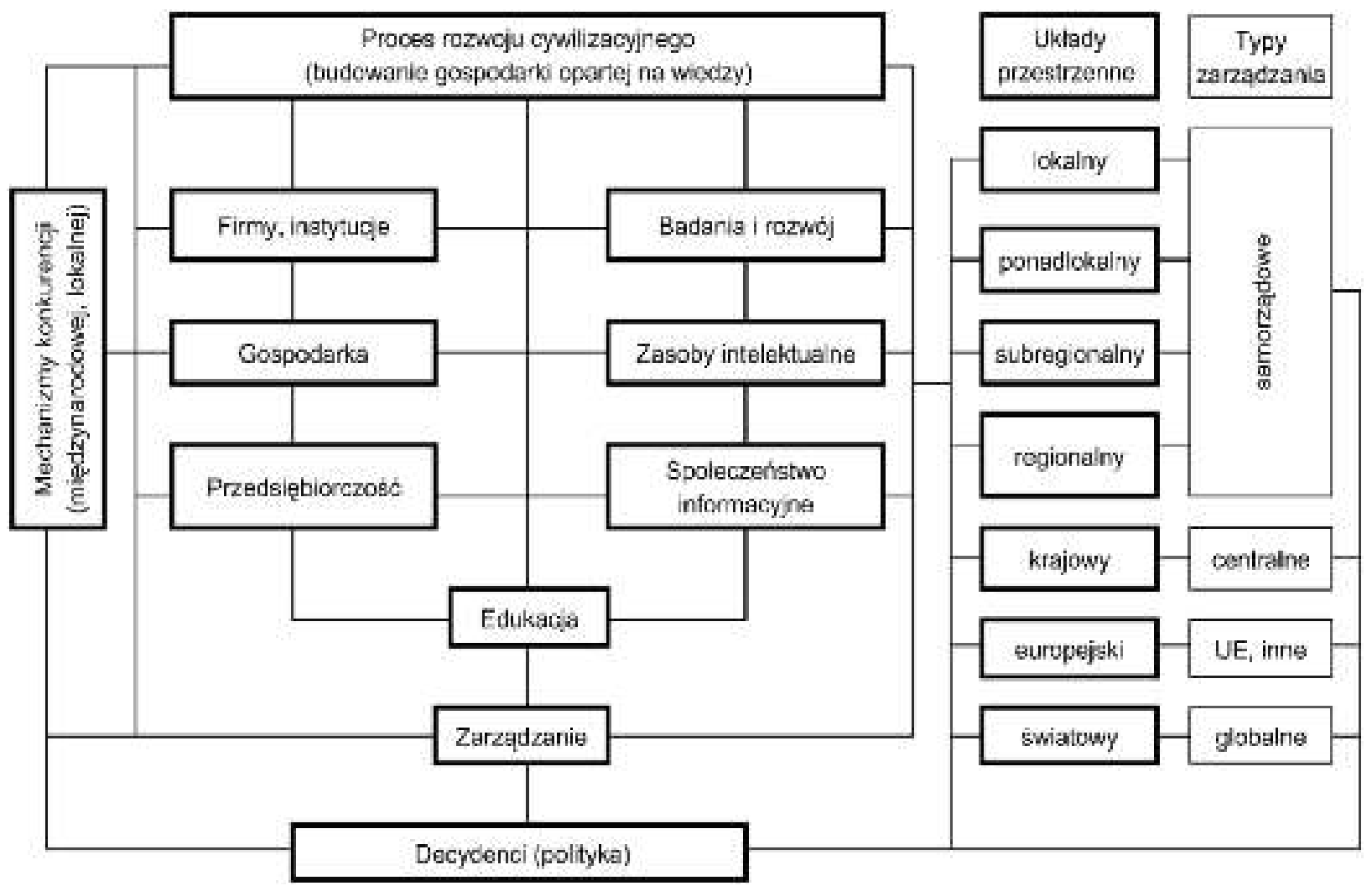

W procesie rozwoju cywilizacyjnego podstawową rolę odgrywają mechanizmy konkurencji, które - oddziałując na decydentów (np. na zarządy firm czy przedstawicieli instytucji) - zmuszają ich do zmiany zachowań i podejmowania określonych działań. 
W pierwszym segmencie modelu szczególnie ważnymi elementami są firmy i instytucje związane z działalnością produkcyjną, produkcyjno-usługową bądź usługową. W wyniku występowania określonych powiązań funkcjonalnych, przejawiających się w różnorodnej ilościowo-jakościowej działalności, wpływają one na określony układ powiązań funkcjonalnych, który przyczynia się do rozwoju poszczególnych sektorów i całej gospodarki (Rachwał 2008; Zioło 1985, 1994). Znaczącą rolę w tym zakresie odgrywają postawy przedsiębiorcze ludzi (w tym właścicieli, pracowników, członków zarządów czy rad nadzorczych) o odpowiednich zasobach kapitału intelektualnego zdobytego i zdobywanego w odpowiednio zorganizowanym systemie edukacyjnym w drodze kształcenia, dokształcania czy doskonalenia.

Funkcjonowanie i przemiany tych elementów dokonują się w określonych uwarunkowaniach, które wynikają z jakości zarządzania i roli w tym zakresie państwa (m.in. poprzez kreowanie odpowiednich instrumentów pośredniego i bezpośredniego oddziaływania) oraz mechanizmów konkurencji, które z różnym nasileniem współwystępują w gospodarce światowej, europejskiej i w określonej skali układów przestrzennych.

Drugi segment reprezentują elementy związane z tworzeniem i upowszechnieniem określonych produktów i postaw, a także wskazywaniem nowych wzorców zachowań produkcyjnych, zarządzania, administrowania, postaw etycznych i in. Wpływają one na wysokość nakładów, ukierunkowanie i jakość prac badawczo-rozwojowych, a także określają spodziewane wyniki oraz stopień nowoczesności przyjmowanych rozwiązań. Efektywność tych działań w znacznym stopniu zależy od potencjału i jakości zasobów intelektualnych decydentów, pracowników elit i całego społeczeństwa. Ważnym zagadnieniem jest więc celowe ukierunkowanie i systematyczne zwiększanie zasobów intelektualnych, które z kolei prowadzą do przyspieszania procesu społecznego, gospodarczego i kulturowego oraz kształtowania się społeczeństwa informacyjnego.

Potencjał poszczególnych elementów związany jest z warunkami i jakością pracy na różnych poziomach edukacji ${ }^{1}$. Proces edukacji jest więc podstawowym czynnikiem wpływającym na podnoszenie potencjału i jakości wyróżnionych wcześniej segmentów obejmujących: firmy, gospodarkę, przedsiębiorczość, badania i rozwój oraz zasoby intelektualne. W zależności od jakości ich działania może następować przyspieszanie lub opóźnianie procesu rozwoju społeczeństwa informacyjnego, a w konsekwencji wkraczanie w fazę gospodarki opartej na wiedzy ${ }^{2}$.

Podstawową rolę w kształtowaniu poziomu i jakości procesu edukacyjnego odgrywa zarządzanie, wynikające z zasobów intelektualnych decydentów (Zioło 2009), którzy przyjmują, a następnie realizują określone cele rozwoju firm i instytucji, a także cele polityki gospodarczej, społecznej, kulturalnej, międzynarodowej i przestrzennej. Oznacza to, że zarówno segment zarządzania, jak i segment podejmowania decyzji zależą głównie od jakości edukacji, poprzez którą przeszli decydenci i które kształtowały zasoby intelektualne całego społeczeństwa.

\footnotetext{
${ }^{1}$ Wskazują na to przytaczane przyczyny pozostawania za granicą młodych pracowników naukowych (A. Stanisławska, I. Redlińska, Drenażu mózgów nie będzie, „Rzeczpospolita”, 30.09.2008 r.). Wśród przyczyn określanych w skali od 0 (niewielkie znaczenie) do 2 (duże znaczenie), na pierwszej pozycji znajdują się: lepsze perspektywy rozwoju naukowego $(1,83)$, lepsze materialne warunki pracy naukowej za granicą $(1,71)$, lepsze organizacyjne warunki pracy za granicą $(1,65)$, wyższe zarobki $(1,55)$, lepsze warunki życia za granicą $(1,53)$, trudności zdobycia pracy odpowiadającej kwalifikacjom w Polsce $(1,23)$ oraz przyczyny rodzinne $(0,92)$.

${ }^{2} \mathrm{Na}$ tym tle należy się zastanowić nad kierunkami przygotowywanych reform systemu edukacyjnego. Niewłaściwe wydaje się naśladowanie wzorców zachodnich bez przestudiowania nowoczesnych myśli polskich reform edukacji, począwszy od idei Komisji Edukacji Narodowej czy sugestii zawartych w dziele Stefana Żeromskiego Uciekta mi przepióreczka. Reformy przy ograniczanych środkach i obniżaniu atrakcyjności zawodu nauczyciela nie mogą przynieść zadowalających rezultatów.
} 
W takim ujęciu samorządy (lokalne, ponadlokalne, regionalne) stają się ważnymi partnerami decydentów (polityków gospodarczych) i przedsiębiorców. Od nich w zasadniczym stopniu zależy atrakcyjność rozwoju danego obszaru, która wynika z jakości procesu edukacyjnego występującego na ich terenie, procesu zarządzania, wdrażania rozwiązań naukowych do praktyki gospodarczej, a w konsekwencji tworzenia podstaw kształtowania gospodarki konkurencyjnej opartej na wiedzy. Współdziałanie tych segmentów jest niezbędne dla przyspieszenia wzrostu gospodarczego, społecznego i kulturowego układów lokalnych, regionów, a w konsekwencji całego kraju, a także układu europejskiego.

Ważną rolę w tym zakresie odgrywa układ krajowy (zarządzanie na szczeblu centralnym), który kreuje określone instrumenty pośredniego i bezpośredniego oddziaływania. Stwarza on odpowiednie uwarunkowania dla stymulowania przemian poszczególnych firm, sektorów czy układów regionalnych, a w konsekwencji wpływa na ich zachowania (wzrost, stagnację czy recesję).

Działalność decydentów dokonuje się w określonych uwarunkowaniach, które wynikają z jakości układu regionalnego, krajowego czy europejskiego (Unii Europejskiej, Europy Wschodniej i relacji sąsiedzkich), a także z sytuacji kształtujących się w skali światowej. Należy zaznaczyć, że pod wpływem nasilających się procesów globalizacji, prowadzących do umiędzynarodowienia działalności gospodarczej, zmieniają się uwarunkowania światowe, które w coraz większym stopniu będą wpływać na procesy przemian mniejszej skali układów przestrzennych ${ }^{3}$.

W świetle przeprowadzonych rozważań należy przyjąć, że relacje między przedsiębiorczością a społeczeństwem informacyjnym zachodzą głównie poprzez segment edukacji. Na nasilenie tych relacji podstawowy wpływ wywiera jakość zasobów intelektualnych społeczeństwa, reprezentowanych przez kapitał ludzki oraz politykę decydentów prowadzoną poprzez kreowanie odpowiednich instrumentów pośredniego lub bezpośredniego oddziaływania.

Przedstawione relacje między wyróżnionymi elementami modelu odnoszą się do cech ilościowych oraz jakościowych. Potencjał elementów oraz ich wzajemne powiązania o różnym stopniu intensywności opisują relacje macierzowe (tab. 1).

W zaproponowanym modelu wzdłuż przekątnej macierzy występują określone relacje zachodzące w strukturze danego elementu, np. relacje w strukturze firmy $(\mathrm{K})$ opisuje $-\left[\mathrm{k}^{\mathrm{k}}\right]$, w strukturze gospodarki $(\mathrm{G})-\left[\mathrm{g}^{\mathrm{g}}\right]$, kształtowaniu przedsiębiorczości $(\mathrm{P})-\left[\mathrm{p}^{\mathrm{p}}\right]$, działalności badawczo-rozwojowej $(\mathrm{B})-\left[\mathrm{b}^{\mathrm{b}}\right]$, kształtowaniu zasobów intelektualnych $(\mathrm{C})-\left[\mathrm{c}^{\mathrm{c}}\right]$.

Wiersze macierzy opisują powiązania aktywne, czyli określają wpływ danego elementu na pozostałe elementy, np. wpływ firmy $(\mathrm{K})$ : na gospodarkę $(\mathrm{G})$ wyraża relacja - $\left[\mathrm{k}^{\mathrm{g}}\right]$, na przedsiębiorczość $(\mathrm{P})-\left[\mathrm{k}^{\mathrm{p}}\right]$, na edukację $-\left[\mathrm{k}^{\mathrm{e}}\right]$ itp. Podobnie wpływ przedsiębiorczości $(\mathrm{P})$ : na firmę $(\mathrm{K})$ określa relacja $-\left[\mathrm{p}^{\mathrm{k}}\right]$, na społeczeństwo informacyjne $(\mathrm{S})-\left[\mathrm{p}^{\mathrm{s}}\right]$ itp. Podobnie w dalszych wierszach został wyrażony wpływ pozostałych elementów (od B do D) modelu na poszczególne elementy (od $\mathrm{K}$ do D).

Kolumny macierzy opisują oddziaływanie pasywne na dany element wszystkich pozostałych elementów, np. oddziaływanie na firmę $(\mathrm{K})$ gospodarki $(\mathrm{G})$ określa relacja $-\left[\mathrm{g}^{\mathrm{k}}\right]$, oddziaływanie na nią przedsiębiorczości $(\mathrm{P})$ relacja - $\left[\mathrm{p}^{\mathrm{k}}\right]$, oddziaływanie: prac badawczo rozwojowych (B) $-\left[\mathrm{b}^{\mathrm{k}}\right]$, zasobów intelektualnych społeczeństwa $(\mathrm{C})-\left[\mathrm{c}^{\mathrm{k}}\right]$, społeczeństwa informacyjnego (S) $-\left[\mathrm{s}^{\mathrm{k}}\right]$, instytucji edukacyjnych $(\mathrm{E})-\left[\mathrm{e}^{\mathrm{k}}\right]$, metod zarządzania $(\mathrm{Z})-\left[\mathrm{z}^{\mathrm{k}}\right]$, decydentów $(\mathrm{D})-\left[\mathrm{d}^{\mathrm{k}}\right]$.

${ }^{3}$ Przykładami są: pogarszająca się sytuacja globalna na światowych rynkach finansowych, wywołana kryzysem finansowym w Stanach Zjednoczonych, nasilający się kryzys paliwowy czy terroryzm, które oddziałują bardzo silnie na układy krajowe, regionalne, a nawet lokalne. Wyrazem tego są zwolnienia pracownicze, które obniżają standard życia i osłabiają tempo wzrostu. 


\begin{tabular}{|c|c|c|c|c|c|c|c|c|c|c|c|}
\hline & 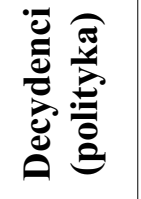 & D & I & top & Za & o & J & $\tilde{i}_{\text {in }}$ & ت0 & $\bar{N}_{N}$ & J \\
\hline & 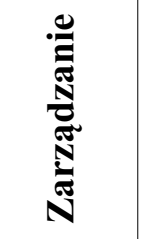 & $\mathbf{N}$ & $\stackrel{N}{2}$ & סم & $\stackrel{N}{2}$ & D & N & $N_{n}$ & No & $N$ & N \\
\hline & 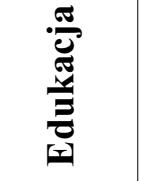 & 되 & $\stackrel{i}{2}$ & id & $\stackrel{2}{2}$ & م & $\ddot{0}$ & in & $\stackrel{0}{0}$ & $\stackrel{\circ}{N}$ & $\ddot{0}$ \\
\hline & 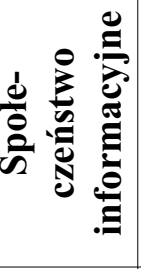 & $\boldsymbol{\Omega}$ & $\underline{n}$ & bD & $\stackrel{n}{2}$ & 0 & o & ${ }_{i n}^{n}$ & s) & $\stackrel{n}{N}$ & 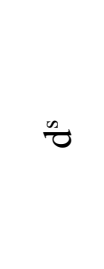 \\
\hline & 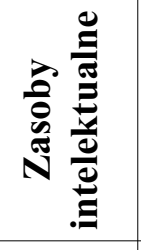 & $U$ & $\stackrel{0}{2}$ & ido & $\stackrel{0}{2}$ & م: & ن & is & ¿ & $\stackrel{i}{N}$ & $\ddot{\nabla}$ \\
\hline & 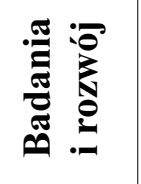 & $\oplus$ & iv & Dos & $\stackrel{2}{2}$ & $\therefore$ & e & in & 。 & $\stackrel{N}{N}$ & च \\
\hline & 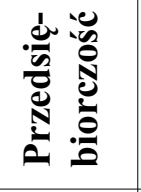 & $A$ & 章 & סิ & בै & 3 & o & is & 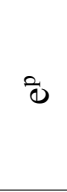 & స̃ & \# \\
\hline & 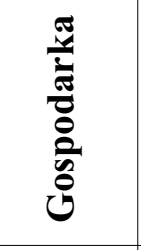 & U & $\stackrel{\text { 步 }}{1}$ & ספס & $\stackrel{\infty}{\Omega}$ & مٌ & 0 & $\stackrel{\text { DD }}{\text { Dn }}$ & DD & $\stackrel{D D}{N}$ & $\frac{\text { on }}{0}$ \\
\hline & 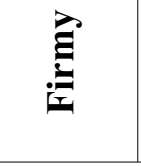 & $\forall$ & $\stackrel{4}{2}$ & 范 & $\stackrel{4}{2}$ & $\ddot{0}$ & $\ddot{0}$ & 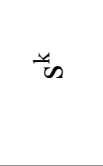 & $\check{0}$ & $\breve{N}$ & $\ddot{\Rightarrow}$ \\
\hline & & & $\underline{V}$ & ט & $A$ & $\oplus$ & $U$ & $\boldsymbol{s}$ & 되 & $\mathbf{N}$ & a \\
\hline & $\begin{array}{l}\vec{e} \\
\text { e }\end{array}$ & & $\underset{\Xi}{\stackrel{\Xi}{\Xi}}$ & 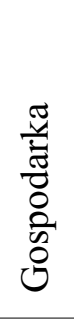 & 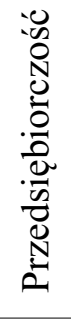 & 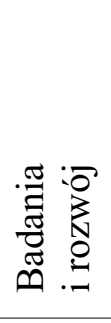 & 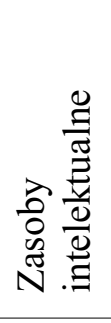 & 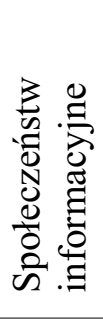 & $\begin{array}{l}\frac{\pi}{8} \\
\frac{\pi}{\tilde{Z}} \\
\frac{3}{I} \\
\text { I }\end{array}$ & 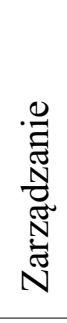 & 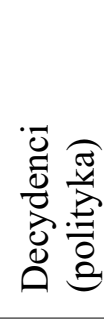 \\
\hline
\end{tabular}




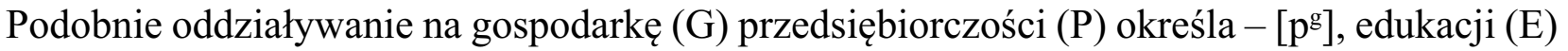
określa [e $\mathrm{e}^{\mathrm{g}}$ ] itp.

Oznacza to, że relacje $\left[\mathrm{p}^{\mathrm{g}}\right] \mathrm{i}\left[\mathrm{g}^{\mathrm{p}}\right]$ nie są sobie równe. Pierwsza z nich $-\left[\mathrm{p}^{\mathrm{g}}\right]-$ ilustruje wpływ przedsiębiorczości na gospodarkę, a druga - $\left[\mathrm{g}^{\mathrm{p}}\right]$ - odnosi się do wpływu gospodarki na przedsiębiorczość. Podobnie odmienny kierunek wpływu określają relacje $\left[\mathrm{k}^{\mathrm{b}}\right] \mathrm{i}\left[\mathrm{b}^{\mathrm{k}}\right]$.

Zaprezentowane podejście modelowe obejmuje całościową problematykę kształtowania przedsiębiorczości i społeczeństwa informacyjnego $\mathrm{w}$ powiązaniu z pozostałymi segmentami (elementami otoczenia). Wydaje się, że model może stanowić dobry wzorzec dla prac badawczych i działań aplikacyjnych mających na celu przyspieszenie procesu kształtowania sie społeczeństwa informacyjnego i skracania dystansu cywilizacyjnego w stosunku do bardziej rozwiniętych struktur społecznych, gospodarczych i kulturowych. Nawiązuje on także do współczesnych idei Unii Europejskiej, która stawia sobie za cel wymianę doświadczeń między regionami europejskimi w zakresie przyspieszania wdrażania przez regiony celów strategii lizbońskiej. Realizacja tego celu prowadzi do pobudzania wzrostu potencjału społecznogospodarczego zróżnicowanych w przestrzeni europejskiej układów regionalnych i lokalnych w oparciu o rozwój zasobów społecznego kapitału intelektualnego. Słusznie się podkreśla, że działanie te są niezbędne dla podniesienia pozycji konkurencyjnej Unii Europejskiej w światowej gospodarce w stosunku do istniejących i intensywnie rozwijających się światowych biegunów wzrostu społeczno-gospodarczego i kulturowego (Stanów Zjednoczonych, Japonii) oraz biegunów nowo kształtujących się (Chin, Rosji i Indii). Podstawową rolę w tym zakresie mają do odegrania odpowiednio przygotowani w procesie edukacyjnym przedsiębiorcy, pracownicy instytucji i decydenci, którzy poprzez wzbogacenie zasobów intelektualnych i wsparcie ich działań wynikami prac badawczo-rozwojowych mogą przyspieszać procesy rozwoju gospodarki opartej na wiedzy i kształtowania społeczeństwa informacyjnego.

W kształtowaniu społeczeństwa informacyjnego bardzo ważnym zagadnieniem są rozwój regionów ${ }^{4}$ i celowe kształtowanie na ich terenie centrów wiedzy. Powinny one obejmować instytuty badań podstawowych, laboratoryjnych, produkcji w skali półtechnicznej (doświadczalnej), związane np. z firmami, które w powiązaniu z uczelniami będą przygotowywały wysoko kwalifikowane kadry naukowe, konstruktorskie oraz kadry związane z organizacją i zarządzaniem nauką. Obecnie w warunkach naszego kraju samo tylko mówienie o centrach i regionach wiedzy nie może dać zadowalających rezultatów. Wydaje się, że barierą w tym zakresie jest brak wiedzy i odpowiedniego przygotowania decydentów różnych szczebli władzy samorządowej i centralnej do tworzenia takich centrów wiedzy. Wyrazem tego, w przeciwieństwie do tendencji światowych, jest brak wyraźnego wsparcia dla rozwoju nauki i prac badawczo-rozwojowych. Uwidacznia się to w niskich nakładach finansowych kierowanych na te cele. Podczas gdy w 2004 r. wiodące korporacje światowe przeznaczały na badania i rozwój znaczne środki, wahające się od 3,10 mld USD do 5,66 mld USD, to w Polsce wydatki na ten cel wynosiły 1,14 mld USD (tab. 2). ${ }^{5}$ Gdyby wydatki krajowe traktować jak firmę, to znalazłaby się ona na 64. pozycji wśród światowych korporacji. W konsekwencji tego podejścia np. środki budżetowe i unijne przeznaczane są głównie na infrastrukturę sieciową, a nie na rozwój nauki czy zwiększanie zasobów wiedzy. Szczególnie ważne jest to na szczeblu lokalnym i regionalnym, gdzie obecnie podstawowym zadaniem powinno być stwarzanie najkorzystniejszych warunków rozwoju edukacji, w tym edukacji informatycznej, edukacji

\footnotetext{
${ }^{4}$ Daje temu wyraz m.in. inicjatywa Komisji Europejskiej - Regions of Economic Change.

${ }^{5}$ W 2005 r. udział nakładów na działalność naukowo-badawczą w PKB Szwecji wynosił 3,9\%, Finlandii $-3,5 \%$, Japonii 3,3\%, Rep. Korei - 3,0\%, Szwajcarii - 2,9\%, Stanach Zjednoczonych - 2,6\%, a w Polsce - 0,6\% (Rocznik Statystyczny RP 2007).
} 
w zakresie kształtowania postaw przedsiębiorczych i zapewnienia jak najszerszego dostępu społeczeństwa do szerokopasmowego internetu. Bez rozwoju edukacji bardzo trudno o nowe osiągnięcia w zakresie badań podstawowych, które następnie możemy wykorzystywać w pracach badawczo-rozwojowych, a ich wyniki stosować do generowania nowych produktów czy usług.

Tab. 2. Wydatki na badania naukowe w $2004 \mathrm{r}$.

\begin{tabular}{|c|c|c|c|}
\hline Lp. & Firmy & Kraje & Wydatki w mld USD \\
\hline 1 & DaimlerChrysler & Niemcy & 5,66 \\
\hline 2 & Pfizer & Stany Zjednoczone & 5,65 \\
\hline 3 & Ford Motors & Stany Zjednoczone & 5,44 \\
\hline 4 & Toyota & Japonia & 5,42 \\
\hline 5 & Siemens & Niemcy & 5,07 \\
\hline 6 & General Motors & Stany Zjednoczone & 4,78 \\
\hline 7 & Microsoft & Stany Zjednoczone & 4,55 \\
\hline 8 & Matsushita Electric & Japonia & 4,42 \\
\hline 9 & IBM & Stany Zjednoczone & 4,17 \\
\hline 10 & Volkswagen & Niemcy & 4,16 \\
\hline 11 & GlaxoSmithKline & Wielka Brytania & 4,01 \\
\hline 12 & Sanofi-Aventis & Francja & 3,96 \\
\hline 13 & Nokia & Finlandia & 3,83 \\
\hline 14 & Johnson\&Johnson & Stany Zjednoczone & 3,83 \\
\hline 15 & Sony & Japonia & 3,60 \\
\hline 16 & Intel & Stany Zjednoczone & 3,52 \\
\hline 17 & Samsung Elektronics & Korea Płd. & 3,40 \\
\hline 18 & Honda Motor & Japonia & 3,36 \\
\hline 19 & Roche & Szwajcaria & 3,30 \\
\hline 20 & Novarti & Szwajcaria & 3,10 \\
\hline
\end{tabular}

Źródło: Monitoring Industrial Research, grudzień 2005, za GW z 21.12.2005 r. 
Reasumując, należy zaznaczyć, że niechęć do współdziałania z nauką to jedna z głównych barier w angażowaniu się we współpracę firm i instytucji publicznych i samorządowych. Aby nowatorskie projekty mogły być zrealizowane i przynosić efekty w badaniach stosowanych (laboratoryjnych, produkcji doświadczalnej czy skali półtechnicznej), potrzebne jest także wsparcie rządu oraz działania zacieśniające współpracę ze środowiskiem naukowym ${ }^{6}$. Należy sobie zdawać sprawę z tego, że środki przeznaczane na badania i rozwój należą do funduszy wysokiego ryzyka. Dobry pomysł wypracowany przez naukę nie wystarczy. Aby dał efekty ekonomiczne, musi przejść wszystkie etapy niezbędne do wdrożenia jego idei w działaniach aplikacyjnych. Równocześnie należy zdawać sobie sprawę z tego, że instytucja oferująca nowe rozwiązania posiada informacje dotyczące popytu na oferowane rozwiązania technologiczne i techniczne oraz ich produkty nie tylko na rynku lokalnym czy regionalnym, ale także na rynku krajowym, europejskim i światowym.

\section{Literatura}

1. Droga Polski do roku 2025, 2005, PAN Komitet Prognoz „Polska 2000 Plus”, Warszawa.

2. Gospodarka oparta na wiedzy, wyzwanie dla Polski XXI wieku, 2001, A. Kukliński (red.), Komitet Badań Naukowych, Warszawa.

3. Nauka-Technologia-Gospodarka,2005, A. Kukliński(red.), Komitet Badań Naukowych, Warszawa.

4. Rachwał T., 2008, Problematyka badawcza funkcjonowania przedsiębiorstw przemystowych [w:] Problematyka badawcza geografii przemystu, „Prace Komisji Geografii Przemysłu PTG”, 11/2008, Z. Zioło, T. Rachwał (red.), Komisja Geografii Przemysłu PTG w Warszawie, Zakład Przedsiębiorczości i Gospodarki Przestrzennej Instytutu Geografii AP w Krakowie, Warszawa-Kraków, s. 53-85.

5. Zioło Z., 1985, Funkcjonowanie i rozwój przedsiębiorstwa przemystowego w przestrzeni geograficznej [w:] Zakład przemystowy w akademickim ksztatceniu nauczycieli geografii, Z. Zioło (red.), „Materiały i Sprawozdania”, z. 16, Centralny Ośrodek Metodyczny Studiów Nauczycielskich, Wyższa Szkoła Pedagogiczna w Krakowie, Kraków, s. 8-24.

6. Zioło Z., 1994, Zmiany otoczenia przedsiębiorstw przemystowych w nowych warunkach gospodarowania [w:] Funkcjonowanie przedsiębiorstw przemystowych w zmieniajacych się warunkach gospodarowania, Z. Zioło (red.), „Materiały i Sprawozdania”, z. 28, Centralny Ośrodek Metodyczny Studiów Nauczycielskich, Wyższa Szkoła Pedagogiczna w Krakowie, Kraków, s. 13-21.

7. Zioło Z., 2009, Procesy ksztaltowania się światowych korporacji i ich wptyw na otoczenie [w:] Wplyw globalizacji $i$ integracji europejskiej na transformacje struktur przemystowych, „Prace Komisji Geografii Przemysłu PTG”, 12/2009, Z. Zioło, T. Rachwał (red.), Komisja Geografii Przemysłu PTG w Warszawie, Zakład Przedsiębiorczości i Gospodarki Przestrzennej Instytutu Geografii UP w Krakowie, Warszawa-Kraków, s. 12-31.

\footnotetext{
${ }^{6}$ Wyrazem braku chęci takiej współpracy są np. trudności w zakresie finansowania badań i wdrażania rewelacyjnych odkryć naukowców z wrocławskiej akademii medycznej, związanych z wykorzystaniem opracowanej przez nich substancji z modyfikowanego lnu do gojenia się poważnych ran.
} 


\section{The Role of the Entrepreneurship in the Forming the Information Society}

There is assumption in the paper that in the new phase of social development new qualitative factors - the development of technology, the qualitative growth of human capital, new instruments for stimulate the development, and the efficiency of public organizations - play the more important role. In this context the attempt was made to mark out the responsibility of the entrepreneurship for forming the information society. 